\title{
Archaeology, heritage, and the material study of religion
}

Article

Accepted Version

Gilchrist, R. and Morgan, D. (2020) Archaeology, heritage, and the material study of religion. Material Religion, 16 (4). pp. 511-517. ISSN 1743-2200 doi:

https://doi.org/10.1080/17432200.2020.1794596 Available at https://centaur.reading.ac.uk/93928/

It is advisable to refer to the publisher's version if you intend to cite from the work. See Guidance on citing.

To link to this article DOI: http://dx.doi.org/10.1080/17432200.2020.1794596

Publisher: Routledge/ Taylor and Francis

All outputs in CentAUR are protected by Intellectual Property Rights law, including copyright law. Copyright and IPR is retained by the creators or other copyright holders. Terms and conditions for use of this material are defined in the End User Agreement.

\section{www.reading.ac.uk/centaur}

\section{CentAUR}

Central Archive at the University of Reading

Reading's research outputs online 


\title{
In Conversation
}

\section{Archaeology, Heritage, and the Material Study of Religion}

\author{
An Interview with Roberta Gilchrist, author of Sacred Heritage: Monastic Archaeology, \\ Identities, Beliefs. Cambridge: Cambridge University Press, 2020
}

David Morgan: You recently published Sacred Heritage (reviewed in this issue), in which you noted that the practice of medieval archaeology has given little regard to heritage studies, on the one hand, and the material study of religion, on the other. Your project seeks to engage the study of medieval archaeology with each of these. I suppose my first surprise reading your book was that archaeologists of the Middle Ages have not always been keenly interested in religion. Please explain that for our readers.

Roberta Gilchrist: Archaeologists have been keenly interested in selective aspects of medieval religion, especially the construction of religious buildings and economic activities connected with the church. But there has been relatively little theoretical reflection on how religion and materiality intersect, for instance how religious beliefs are connected to spaces and objects through embodied material practice. Until recently, there was a tendency in the wider study of later medieval archaeology (c. 1000 CE onwards), to prioritize economic questions and to engage less explicitly with social theory. For comparison, the study of gender archaeology is also less developed for the later medieval period than in other branches of archaeology. A new generation of medieval archaeologists is now posing important social questions around ritual, but it's striking that they're not drawn to the study of organized religions. Instead, they highlight archaeological evidence for rituals that took place outside the institutional domain of the medieval church and clergy, what we might call 'lived religion'. Materiality is considered in terms of domestic rituals, burial practices and folk rituals in the landscape, rather than in relation to the archaeology of churches and monasteries. This preference may stem partly from the disciplinary identity of medieval archaeology - a relatively new subject that has found its place in revealing 'history from below', the subaltern voices omitted from the written documents and material culture produced by medieval elites.

DM: And the second surprise for me was that a rift exists between the archaeological study of the [medieval] past and the study of heritage as the past come down to the present. How do you account for that disconnect?

RG: I think the disconnect may result from the same reluctance to engage critically with social theory and social questions. In this case, it's a reticence to reflect on how medieval archaeology contributes to the contemporary construction of medieval heritage as a political and cultural process. The discipline has addressed more applied questions of heritage management, but there are few critical commentaries on how medieval archaeology is enmeshed with political, cultural and power relations in the present. For 
example, we are only just beginning to think about how twentieth-century traditions of scholarship have informed interpretative narratives for the presentation of public monuments such as castles and monasteries and conservation practices in churches and cathedrals that are still in use for religious worship. The places of medieval religion represent a very high proportion of the tangible heritage that survives from medieval Europe. But we have not reflected sufficiently on the social factors that shaped their survival and how archaeological knowledge suffuses conservation practice, public interpretation and social discourses around medieval heritage.

DM: Why is it that, in your words, "neither archaeologists nor heritage practitioners have given sufficient consideration to spiritual value in shaping contemporary understandings of medieval European heritage" (p. 3)?

RG: There are perhaps two separate barriers, one rooted in heritage studies and the other in archaeology. Prevailing approaches to cultural heritage management prioritize professional assessments of 'heritage value' based on academic criteria such as historical importance and aesthetic quality, rather than social value. This is compounded by the emphatically secular outlook of archaeology as a discipline, which characterizes religion principally in terms of economic power relations, and invites little reflection on the concept of the numinous in the past (or the present). However, there has been a recent shift towards 'living heritage' approaches, which emphasize the social and community significance of heritage. This was prompted by global recognition of the concept of 'intangible heritage', the oral traditions, myths, rituals, knowledge and skills that provide communities with a sense of identity and continuity. It opens up questions about 'spiritual value', that is, how contemporary communities interpret the significance of heritage based on their spiritual beliefs, broadly defined. I see the 'spiritual' value of heritage as the more holistic experience and perception of religious sites and landscapes. It's closely bound up with wellbeing and aesthetic value, the sensory and visual qualities of heritage that are experienced on an individual basis. Spiritual heritage is not incompatible with secular society or humanist values; for example, it is sometimes tied to personal reflections on mortality or collective loss (such as battlefields).

DM: Talk about "spiritual value" and "sacred heritage" makes many people nervous. Do we need to be concerned about this terminology? Does it imply any sort of advocacy that might press scholarship in favor of a religious disposition?

RG: In my view, it is the not the role of scholars to advocate religion. My aim is to encourage critical reflection on sacred heritage and the role of beliefs in the past and the present, bringing together explorations of tangible and intangible heritage. Archaeologists have explored multi-vocality in the interpretation of prehistoric sites such as Stonehenge, which holds spiritual significance for contemporary neo-pagans. We also need to think about multi-vocality in relation to medieval sacred heritage. We might investigate how sacred places were contested by competing religions, how they were transformed over time, and how material culture was invoked in religious conflict. The continuing relevance 
and sensitivity of these issues today is highlighted by recent debate around a notorious anti-Semitic image at Wittenberg Stadtkirche (Germany), dating to the thirteenth century.

A Jewish pensioner petitioned for removal of the 'Judensau' bas-relief, which depicts a rabbi peering into a pig's anus (an unclean animal), while others suckle from its teats. The court rejected the petition, on the grounds that the image was placed in 'memorial context' by an explanatory sign and was therefore not offensive to Jews. This legal case illustrates why archaeologists and heritage practitioners need to engage critically, to interrogate sacred heritage in its medieval and contemporary social contexts. Medieval sacred heritage is not neutral or inert - it carries social and political capital and ethical ramifications.

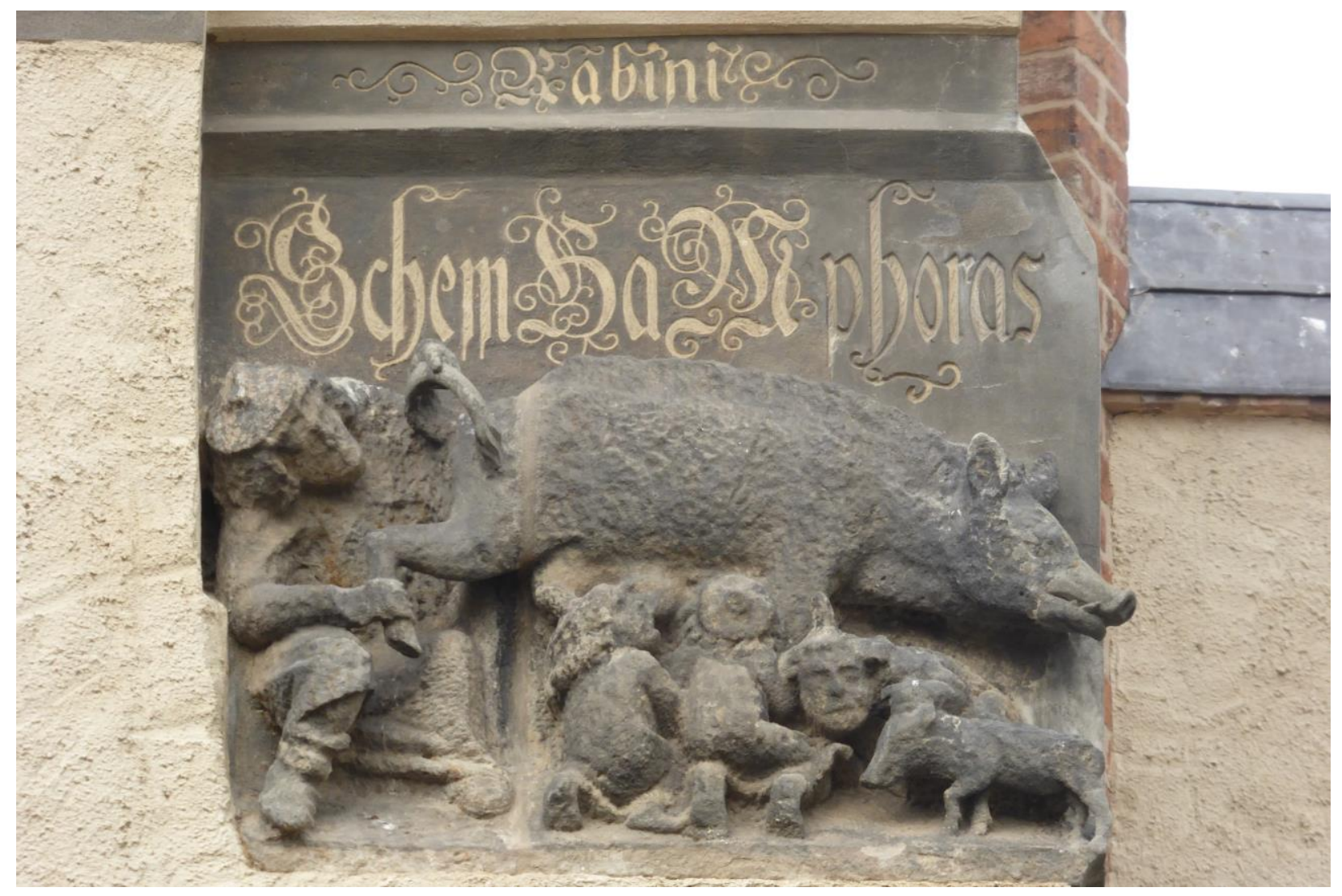

'Judensau' bas-relief, Wittenberg Stadtikirche (Germany)

https://commons.wikimedia.org/wiki/File:Judensau Wittenberg.jpg Posi66 / CC BY-SA (https://creativecommons.org/licenses/by-sa/4.0)

DM: You have much to say about Scottish monasticism in your book. I was surprised by your claim that there "has been relatively little interdisciplinary or theoretical engagement to address social questions about Scottish monasticism in the later Middle ages or its wider material character" (p. 39). Your interest in 'identity', as signaled in the title of the book, 
comes to the fore here. Does the connection between identity and belief have much to contribute to engaging medieval archaeology with religion?

RG: My title refers to 'identities' in both the present and the past, while the Scottish case study examines the dynamics between national identity and the practice of medieval archaeology. The social study of monastic archaeology in Scotland has focused on the early medieval (Celtic) period, widely perceived as a 'golden age'. In both Scotland and Ireland, Celtic monasteries have been valued as the apogee of native culture, while monasticism dating from the twelfth century onwards carries the negative connotations of AngloNorman colonization. In the current political context of Scottish independence, key questions for engaging medieval archaeology with religion are around regional distinctiveness and indigeneity, that is, how monastic material culture responded to local beliefs. I harness research questions usually applied to Celtic monasteries and use them to interrogate later medieval monasticism, thereby disrupting the dualistic ethnic framework of Celtic vs Anglo-Norman. Research on Celtic monasticism has prioritized questions of indigenous innovation and continuity of tradition, proposing that early medieval practices were influenced by prehistoric rites. I reveal archaeological evidence for how the panEuropean model of monasticism was 'Scotticized' in the twelfth century through material practices, for example in retaining elements of earlier burial rites and maintaining continuity of siting for sacred places. I also draw out significant transformations, such as the adoption of cloisters as part of the shift from eremitic (solitary) to coenobitic (communal) monasticism, and, significantly, the new opportunities for religious women that were introduced by reformed monasticism in the twelfth century.

DM: In your third chapter, on monastic healing, you focus on the materiality of religion as practice-based care for the body. Embodiment has become in the last two decades a focus in the study of religion, in part from phenomenology-one thinks of the important work by the anthropologist Thomas Csordas - and in part, at least in the United States, from the influence of the study of 'lived religion,' that is, the religious practices of everyday life, particularly domestic culture. But one should also look further back to the classic work of Marcel Mauss on "techniques of the body." Tell us how this applies to the study of medieval life in Britain.

RG: Mauss's essay on 'techniques of the body' (1934) is the direct ancestor of Bourdieu's theory of habitus (1977) and was described fittingly by Levi-Strauss as 'an archaeology of body habits'. It informed my earlier study of the archaeology of the medieval life course (2012), focusing on 'techniques' of birthing practices and childcare, adolescence and adult life, and care of the body, including those of the dead. Monastic 'techniques of the body' were highly disciplined and specialized, codified through monastic rules and ritualized through rites of profession. Archaeologists have identified characteristic assemblages of artefacts at medieval monasteries that were actively engaged in shaping monastic constructs of space, time, dress, diet, hygiene and therapeutic treatments. I argue that religious beliefs and identity were produced through repeated and habitual interaction of this material culture with techniques of the monastic body. However, Mauss also reminds us to pay due regard to historical and cultural specificity - recent archaeological research 
confirms that monasticism was reinterpreted for local application and changed significantly through time.

DM: In light of the long bias in religious studies (think of Tylor, Frazer, Durkheim, and Weber, for instance) regarding a sharp differentiation of magic and religion, I was very encouraged to see you focus in the fourth chapter (on "the materiality of magic") on the relationship between the two. Why is this important for your project?

RG: I'm interested in breaking down the traditional dichotomy that has been perpetuated between the study of 'institutional' vs 'lived' religion. Focus on magic has the potential to highlight religious agents who are generally absent from orthodox histories, in particular women, who played a crucial ritual role in caring for the spiritual and physical wellbeing of medieval communities. The evidence of medieval burial practices has been especially important in detecting objects and materials that may have been employed in magic for the dead. Visual sources (Books of Hours) indicate that it was women who washed and prepared the corpse for burial and therefore had the opportunity to place items within the shroud. Only a small proportion of later medieval graves included objects, such as coins, crosses, pilgrim souvenirs, 'antique' artefacts, and organic materials including stones, shells and wooden staffs. The intended purpose of these grave goods is not recorded, but I interpret these objects as broadly apotropaic, protecting loved ones from the perils of purgatory. Infants and children were singled out for special funerary treatment, both through the inclusion of amuletic materials and in the siting of their graves. Through the lens of magic, we glimpse the ritual agency of medieval women and the role of material culture in negotiating emotional bonds between generations, and between the living and the dead.

DM: Your discussion of 'natural magic' was intriguing. How is a substance naturally magical? Can we discuss this as an affordance, that is, as an actual material characteristic that exerts some mode of agency? Or is natural magic never more than lore or hermetic philosophy? For example, what is the difference between saying that a certain gemstone has the occult quality of healing leprosy and that crude oil has the property of combustability? It occurred to me that the early modern magus Paracelsus and after him Jakob Böhme, both taught that there are signatures in the physical properties of everything in nature that form a kind of language that alerts the adept to internal or hidden qualities. This is later than the period you are studying, but is that the sort of thing you have in mind? If so, is it part of a long hermetic and alchemical tradition?

RG: Absolutely, the medieval notion of 'natural magic' is directly relevant to understanding the perceived affordances and agencies of objects and materials. The model emerged in the thirteenth century, blending classical ideas around the 'virtues' of natural substances such as stones, herbs and animals (from Pliny and Galen), with Christian ideas about the cosmos. Theologians debated the causation of magic in relation to the natural order - in other words, whether the agency attributed to marvels could be regarded as 'above nature', 
'beyond nature' or 'against nature' (Thomas Aquinas). Natural magic, such as the widespread use of gemstones, was believed to draw its power from the natural world, which was perceived as divinely created, and therefore benign. However, archaeological evidence suggests that elements of these beliefs were in place much earlier and were perhaps absorbed within the conceptual framework of natural magic. For instance, prehistoric burials in parts of Britain incorporated stones of white quartz. This distinctive rite persisted in Scotland, Wales and Ireland, sometimes well into the medieval and postmedieval periods. Quartz is piezoelectric: when struck or rubbed it will produce a faint glow. Its physical properties must have marked it out as a special material, valued by local communities over centuries, and which could be explained to medieval people through the framework of natural magic.

DM: The topic of memory comes under careful attention in your book. Memory is not factual regurgitation, but something much more mythical, creative, and driven by the cultural politics of identity. It is also highly selective and often interlaced with forgetting. How does all this play out with the ruins at Glastonbury?

RG: Glastonbury demonstrates how social memory is activated by certain places and how it is reinvented over time, to serve different social narratives. The monks of Glastonbury Abbey promoted two distinct origins myths that secured their international prestige and have continued to shape cultural identity. They proposed that the abbey was the site of the earliest Christian church in northwestern Europe, founded by the biblical figure of Joseph of Arimathea in the first century. They also asserted that King Arthur had died at Glastonbury in the fifth century - and in 1191, they claimed to have dug up the grave of Arthur and Guinevere. There are some kernels of truth to the abbey's early origins, including archaeological evidence for settlement in the sixth century. But historians agree that these stories were fabricated to attract funding, much needed after a major fire in 1184 had destroyed the abbey. What's fascinating is how the monks used material practices to establish a tangible presence for these myths - forging Arthurian artefacts, siting Arthur's mausoleum at the high altar of the great church, employing early signage to explain these stories to pilgrims, and creating a chapel and hagiography for Joseph, to perpetuate his reputation as Glastonbury's saint. After the dissolution of the abbey in 1539, the Arthurian legend was quickly forgotten, whereas Joseph of Arimathea was promoted by the Protestant state to legitimate England's separation from Rome. Joseph was heralded as the first Protestant preacher, who established the first English church long before the Roman mission to convert England (597CE). Joseph's myth was reworked through material practices focusing on the chapel dedicated to him, including its deliberate preservation as a Protestant relic. 


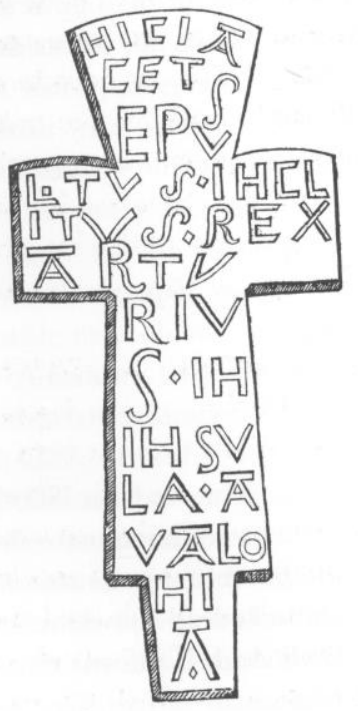

Lead cross claimed to have been found in Arthur's grave in 1191, at Glastonbury Abbey, Somerset. This forged object was modelled on earlier mortuary crosses. The inscription read: HIC JACET SEPULTUS INCLITUS REX ARTURIUS IN INSULA AVALONIA (Here lies buried the famous King Arthur in the island of Avalon) (engraving from Camden, 1695)

DM: Glastonbury seems like a veritable laboratory for studying heritage. The past and the present face one another, sandwiching a thick layer of myth and imagination. Why has this particular place experienced the ongoing investment of interest that it has?

RG: Perhaps it has something to do with the evocative character of the natural landscape the distinctive topography has attracted this thick layer of myth, creating a unique sense of place. The focal point is a sandstone pinnacle known as Glastonbury Tor, which rises $158 \mathrm{~m}$ above the surrounding flat terrain of marshes. Before its drainage in the medieval period, the area was a watery landscape. The Tor rose dramatically from the water, drawing early settlers and eventually early medieval monks. In the context of medieval Britain, the isolation of desert monasticism could be founded in marginal, watery landscapes such as this. The monks of Glastonbury Abbey created origins myths that resonated with national identity and which have proved to be surprisingly durable. The Arthurian stories achieved prominence again in the early twentieth century, when Glastonbury was briefly a beacon for crafts, music and performing arts, as well as enticing Christian mystics. Glastonbury emerged as a magnet for New Age beliefs from the 1970s, spurred by the Glastonbury Festival, and from the 1990s, has been the focus for the eco-feminist Goddess movement. Glastonbury is a sacred landscape that seems to invite diverse and contested versions of its past, all of which are rooted in myths as a means of connecting place with spiritual and ancestral relationships. 


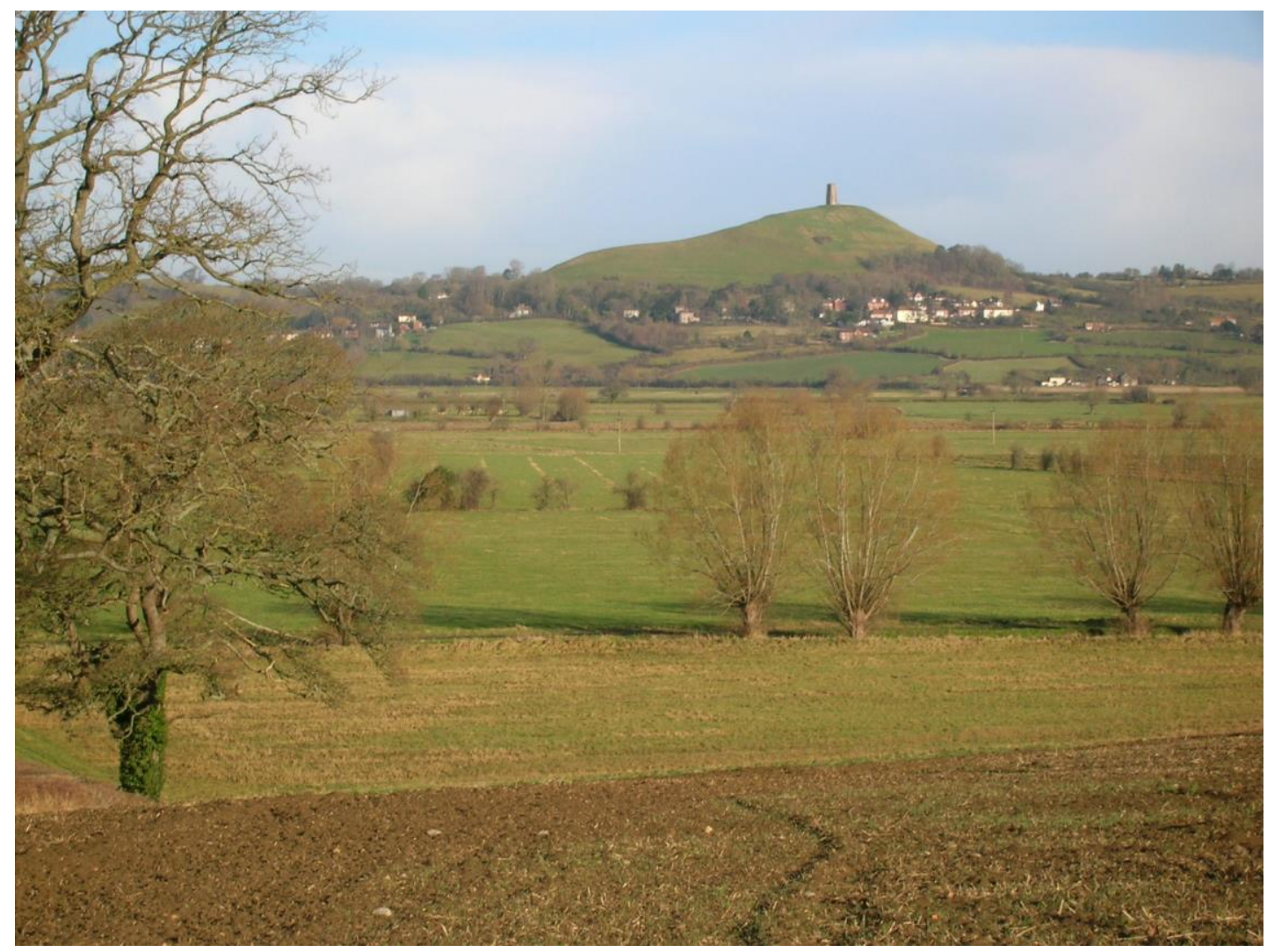

Distant View of Glastonbury Tor, Somerset, England, 2009, photo by Tony Grist, Public Domain, https://commons.wikimedia.org/wiki/File:Glastonbury Tor 3.jpg

DM: The problematic category of 'authenticity' lies at the heart of your final chapter. You describe it as a kind of "sacred myth" (176). One can easily recognize the relevance of the category in the medieval era-relics, for instance, within the medieval domain of plausibility had to be the 'real' thing, the remains of a particular saint, in order to deliver the favors that devotees sought from the saint. The Church was alarmed by the market in fake relics and sought to regulate the distribution of relics and forbade their sale. In the modern era, the term authenticity shifts to designate another notion of 'the real thing.' The quest for the original, rare, or genuine is capitalized by dealers, collectors, museums, and the market in antiquities, but also by the practice of heritage preservation. How has this shift affected heritage studies and archaeology and their varying conceptions of 'value'?

RG: Current debates around authenticity have been influenced by new thinking on intangible heritage and living heritage. Previously, authenticity was a means of judging 'value' based on professional criteria of antiquity, quality and extent of material survival. Now, there is growing recognition that understandings of authenticity are culturally constructed and relative. The beliefs of local communities about their heritage are just as important in defining authenticity as specialist assessments of historicity. This democratic principle presents new opportunities for inclusive and multi-vocal interpretations that will 
speak to more diverse audiences engaging with heritage. However, it also presents additional challenges in terms of preserving and managing heritage, potentially bringing heritage professionals and local communities into conflict. I believe that the more traditional (materialist) designations of authenticity may still be relevant to communities engaged with sacred heritage sites. The authentication of early origins and the survival of original fabric are crucial in validating their unique sense of place and the numinous. Tangible and intangible heritage are brought together at sacred sites: authenticity is sometimes a strategy for people to negotiate their own spiritual beliefs in relation to sacred landscapes, buildings and objects. The material study of religion has an essential role to play here: elucidating the sensory qualities of religion and making the past more accessible, creating spaces for people today to experience sacred sites and material culture, and to draw their own meanings from them.

Roberta Gilchrist is Professor of Archaeology and Research Dean for Heritage and Creativity, University of Reading, UK. Email: r.l.gilchrist@reading.ac.uk

David Morgan is Professor of Religious Studies at Duke University, USA, and an editor of Material Religion. Email: david.morgan@duke.edu 